University of Montana

ScholarWorks at University of Montana

Graduate Student Theses, Dissertations, \&

Professional Papers

1975

\title{
Convergent and discriminant validity of the test of sensitivity
}

Marianne Thomas Spitzform

The University of Montana

Follow this and additional works at: https://scholarworks.umt.edu/etd

Let us know how access to this document benefits you.

\section{Recommended Citation}

Spitzform, Marianne Thomas, "Convergent and discriminant validity of the test of sensitivity" (1975). Graduate Student Theses, Dissertations, \& Professional Papers. 5607.

https://scholarworks.umt.edu/etd/5607

This Thesis is brought to you for free and open access by the Graduate School at ScholarWorks at University of Montana. It has been accepted for inclusion in Graduate Student Theses, Dissertations, \& Professional Papers by an authorized administrator of ScholarWorks at University of Montana. For more information, please contact

scholarworks@mso.umt.edu. 
CONVERGENT AND DISCRIMINANT VALIDITY OF THE TEST OF SENSITIVITY

By

Marianne Spitzform.

B.S. Allegheny College, 1968

M.T.S. Harvard Divintty Schoo1, 1970

Presented in partial fulfillment of the requirements for the degree of Master of Arts

UNIVERSITY OF MONTANA

1975

Approved by;

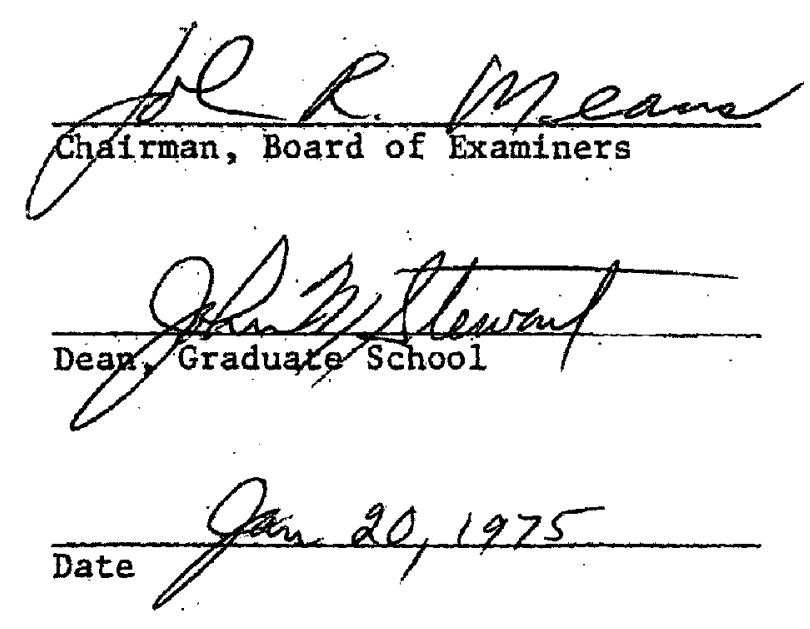


UMI Number: EP41071

All rights reserved

INFORMATION TO ALL USERS

The quality of this reproduction is dependent upon the quality of the copy submitted.

In the unlikely event that the author did not send a complete manuscript and there are missing pages, these will be noted. Also, if material had to be removed, a note will indicate the deletion.

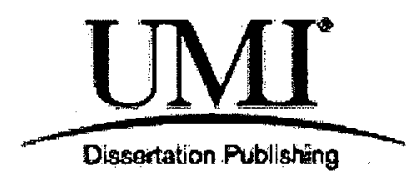

UMI EP41071

Published by ProQuest LLC (2014). Copyright in the Dissertation held by the Author.

Microform Edition (C) ProQuest LLC.

All rights reserved. This work is protected against unauthorized copying under Title 17, United States Code

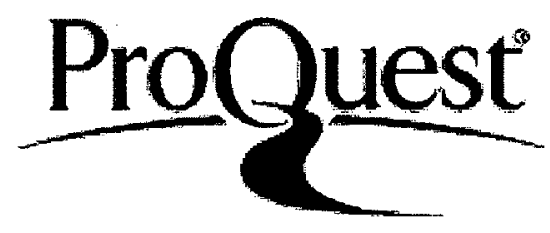

ProQuest LLC.

789 East Eisenhower Parkway

P.O. Box 1346

Ann Arbor, MI 48106 - 1346 
Convergent and Discriminant Validity of the Test of Sensitivity

Director: John R. Means $K^{M}$

Smith's Test of Sensitivity was examined through Campbell and Fiske's multitrait multimethod approach. The traits intelligence and sensitivity were measured by three distinct methods: objectively scored tests, peer ratings and self ratings. A total of 53 subjects comprising 10 work or living groups were sampled from undergraduates, graduates, and employees of the University of Montana.

Significant differences between subject groups were found on intelligence test scores but not on sensitivity test scores. There was no evidence of sex differences on sensitivity scores. The multitrait multimethod correlation matrix revealed that there was no convergent validity on measures of sensitivity at the .01 probability level. while significant correlattons did result on measures of intelligence. The multitrait multimethod approach showed that trait rather than method variance was responsible for the differences between intelligence and sensitivity correlations.

The fallure to find convergent validity for Smith's Test of Sensitivity should be considered before employing this instrument for the measurement of sensitivity. Data from the present study suggest that alternatively 1) sensitivity is not a unified personality tralt or 2) Sinth's Test of Sensitivity simply does not adequately tap the trait sensitivity. 
TABLE OF CONTENTS

Page

ABSTRACT $\ldots \ldots \ldots \ldots \ldots \ldots \ldots \ldots \ldots \ldots \ldots \ldots \ldots$ i1

LIST OF TABLES $\ldots \ldots \ldots \ldots \ldots \ldots \ldots \ldots \ldots \ldots \ldots \ldots$ Iv

Chapter

1 INTRODUCTION

2 METHOD

SUBJECTS

INSTRUMENTS

PROCEDURES

3 RESULTS 11

4 DISCUSSION 14

5 SUMMARY 19

REFERENCES $\quad 20^{\circ}$

APPENDICES 
LIST OF TABLES

$\because$ Page

TABLE 1

Multitralt Multimethod Matrix

12 


\section{Chapter 1}

\section{INTRODUCTION}

A Test of Sensitivity was developed by Smith (1973) to empirically measure sensitivity, defined as the degree to which one person can predict another person's feelings, thoughts and behavior. Smith believes that sensitivity can be broken down into four components: Observational sensitivity is the ability to look at and listen to another person and remember what he looked like and said. Nomothetic senstivity is the ability to learn about the typical member of a group and to use this knowledge in making more accurate predictions about individuals in that group. Idiographic sensitivity is the ability to use increasing exposure to and information about a person In making increasingly accurate predictions about him. Theoretical sensitivity is the ability to select and use theories to make more accurate predictions about others. While Smith believes that sensitivity can be subdivided into the components listed above, the Test of Sensitivity was developed to measure sensitivity as a general ability. Cline and Richards (1960) offered a different conceptualization of sensitivity on the basis of a study they conducted which required a wide range of predictions about people presented on sound films to fifty judges. Cline and Richards believe that there is a general ability to perceive others accurately. This general ability, similar, perhaps, to the $G$ factor in intelligence, consists of at least two 
parts: Sensitivity to the Generalized Other and Interpersonal Sensitivity. Sensitivity to the Generalized other is thought to be comparable to what Cronbach labelled Stereotype Accuracy. Interpersonal Sensitivity is called Differential Accuracy in Cronbach's terminology - the ability to predict specific differences between individuals.

As noted above, the Test of Sensitivity examined in this study is presented by Smith as a measure of sensitivity as a general ability. Smith's primary concern in developing the Test was in selecting individuals in need of sensitivity training. "Without measures, we cannot select those who need training, design programs to meet the need, give trainees knowledge of the progress they are making, or evaluate the effectiveness of the training they have had. (p. 10)."

Smith's Test contains thirteen one to two paragraph descriptions taken from actual case histories, followed by a series of true/false questions ( 76 in al1) which ask the examinee to predict the behavior of the person described in specific situations. Testretest and odd-even Item reliability has been given as .70 , but no valldity studies have been reported to date.

Smith noted that the validity of the Test of Sensitivity might be challenged from the standpoint that it assumes that sensitivity is a general ab1lity. "It stresses what is common to making true or false predictions about different people in different situations (p. 22)." 
In undertaking to assess the convergent and discriminant validity of the Test the present study provides data bearing on Smith's assumption.

Let us briefly examine the possible relationship of sensitivity and empathy. From the standpofnt of clinical application, empathy has received considerably more attention than sensitivity. There has, of course, been a sizeable amount of research devoted to empathy, particularly as empathy affects therapeutic outcome. How are sensitivity and empathy related? The terms have been treated interchangeably. As recently as 1971 in a study by Campbell, Kagan and Krathwohl, the terms "affective sensitivity" and "empathy" were used as synonyms. Truax, in 1963, stated that his Accurate Empathy Scale was designed to measure a conception of empathy "which involves the sensitivity to current feelings, and, the verbal facility to communicate this understanding in a language attuned to the patients' feelings. . . The therapist's responses not only indicate a sensitive understanding of the apparent feelings but serve to clarify and expand the clients' awareness of his feellngs or experiences. (p. 257)." (my underlines) Empathy, according to Smith, is the vicarious experiencing of the feelings, thoughts or attitudes of another person - the degree to which one can subjectively assume the world view of the other. In contrast, sensitivity is defined by Smith as the degree to which one person can predict another person's feelings, thoughts and behavior. He believes that this emphasis on the element of prediction is the basis on which to distinguish sensitivity from empathy. Let is put 
aside this discussion for the present in order to further consider the measure of sensitivity which Smith has proposed.

The purpose of this study was to examine the convergent and discriminant validity of Smith's Test of Sensitivity in an attempt both to gain information about the Test and to shed some light on the issues outlined above, namely, the nature of sensitivity and its relationship to empathy.

Smith has noted that one way to determine the validity of the Test of Sensitivity would be to compare test scores with nominations from intimates. Incorporating this suggestion, a Campbell and Fiske multitrait multimethod approach was chosen for the present study. Campbell and Flske (1959) wrote that "in order to examine discriminant valid1ty and. . relative contributions of trait and method variance, more than one trait as well as more than one method must be employed in the validation process (p. 81)." The thrust of the multitrait multimethod approach is to examine the relationships between different methods of measuring the same trait (if correlations are high this is evidence of convergent validity) and the relationships between supposedly different trafts on the same methods. This second set of relationships defines discriminant validity. "For the justification of novel trait measures, for the validation of test interpretation, or for the establishment of construct validity, discriminant validation as well as convergent validation is required. Tests can be invalidated by too high correlations with other tests from which they were intended to differ (p. 81)." 
Use of the Campbell and Fiske model requires selection of at least two traits and two methods of measuring those traits. Three methods were utilized in the present study: objectively scored tests, peer ratings and self-ratings. IQ was selected as the second trait 1) because of the overall reliability and validity of available measuring Instruments and 2) because of speculation that a general intelligence factor might encompass what is generally considered to be sensitivity. If this speculation proved to be accurate we would expect to fail to find discriminant validity. Differences of opinion on this point required an attempt at empirical resolution.

The primary hypothesis on which this study was based was: The Campbell and Fiske multitralt multimethod matrix will provide evidence of both convergent and discriminant validity on the trait sensitivity. Hypotheses of secondary importance included: a) There w111 be no difference in sensitivity between males and females as measured by the objectively scored test. b) There will be significant differences between groups of intimates serving as subjects on the Test of Sensitivity. c) Sensitivity as measured by the objectively scored test will be higher for those subjects who are participating in an ongoing encounter group than for subjects who are not. 


\section{Chapter 2}

\section{METHOD}

SUBJECTS

The use of peer ratings limited subject selection for the purposes of this study to small groups of Individuals who worked or I1ved together or had some common functions that brought them into close contact. An arbitrary limit was imposed, i.e., a history of six months of such proximity for sufficient knowledge to make meaningful peer ratings. In an attempt to sample a broad range of intelligence, education, and general living experience, subject groups were chosen from undergraduate students, graduate students and employees at the University of Montana. In addition, an effort was made to select a combination of all male, all female and mixed sex groups. Data were collected on a total of 10 volunteer groups which included 53 subjects. Undergraduates represented such groups as a sorority, the University Dance company, a wing in a dormitory, and students working in the recreation department. Graduate students sampled included groups from microbiology, English, and guidance and counseling. Employee subjects were drawn from a secretarial pool and two different areas of the food service.

\section{INSTRUMENTS}

The seven point scales shown below were utilized for both peer ratings and self ratings. A pilot study using subjects chosen at random in the Copper Commons of the University Center was conducted to assess differences in the wording of the question for peer ratings. 
The concern here was to choose the wording which encouraged the selection of the broadest range of values. 1
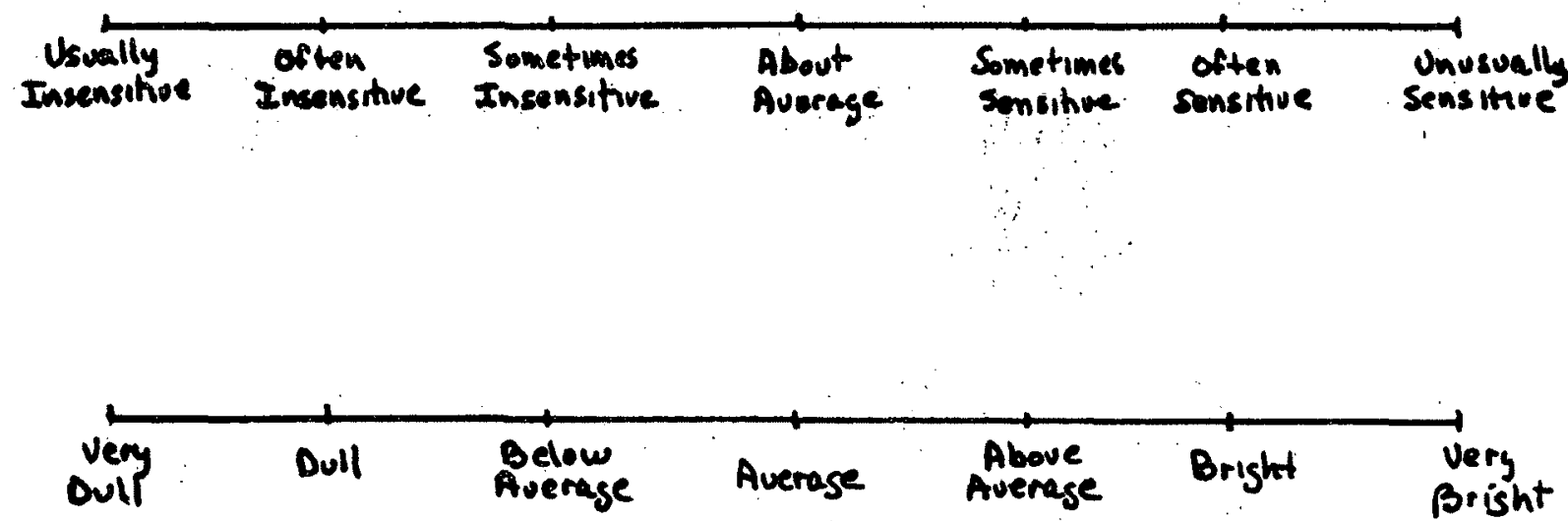

In addition to these seven point scales for sensitivity and intelligence, materials Included the Test of Sensitivity (found in its entirety in Appendix A) and the Ammons Quick Test.

The Ammons Quick Test measures Intelligence through a picturevocabulary approach. It makes use of pictorlal representations, among which the testee chooses that one which best illustrates the concept given by the examiner. Three forms of the Quick Test are avallable and all three forms were administered to each subject. Reliablity and validity coefficients for this instrument are quite high. Rellabilities as reported by the authors range from .86 to .96 for Form $A$ with Form $B$, while validities range from .48 to .91 with various forms of the Stanford-Binet and Wechsler Intelligence Scale for Chlldren. More information is available in the Quick Test Appendix B.

1. More information on this pilot study is avallable in 
Provisional Manual.

Subjects were also asked for their own definition of sensitivity in a multiple choice question with the following alternatives: 1) The ability to relate with care and concern to other people. 2) The abllity to perceive and appreclate small differences. 3) The ability to react to stimuli. 4) The ability to predict a person's feelings, thoughts and behavior.

In addition, to compare predictions and behaviors more directly, the following questions were asked. "What do you think each of these people scored on the Test of Sensitivity? (A score of 59 or above is high, 42 or below 1s low)." "On the scale below, choose the number for each of these people which represents how sensitive you think they think they are." In each case names were supplied of other Individuals from that subject's group.

\section{PROCEDURES}

When initial contact was made with prospective subjects, usually by telephone, they were glven the following lnformation.

As part of my Masters degree in clinical psychology I am conducting a research study on communication and interpersonal relationstips. I am interested in learning more about how small groups of people who 11ve or work together perceive each other. I would like very much to have you (and/or your group) particlpate in my study. This would involve your meeting with me for approximately one hour, to be scheduled at your convenience. During that hour I w11l ask you to complete a number of forms and questions. All of your answers will be completely confidential and your name will not be used in any reports. Your (supervisor, president; etc.) knows of my study and has agreed to participate. 
Subjects were seen at the Clinfcal Psychology Center from late February through May, 1974. Since all measurements except the Quick Test were self-administered, appointments were scheduled to overlap when possible.

Instructional sets for each measure are given below.

The Quick Test: "I am going to show you some pictures and read some words. You point to the best picture for the words. Some of the words w11l be very easy and some of the words will be hard. You won't know all the words. If I read a word that you don't know, just tell me that you don't know and I will go on to another word." The Test of Sensitivity: How well can you predict the feelings and behavior of people? In each of the following actual cases some information is given about a person. Study the facts; then pick the answer to each statement that you think is correct. Circle ' $\mathrm{T}$ ' on the answer sheet if you think the statement is true; ' $F$ ' if you think it is false. The correct answers are known from more complete Information about the individuals.

Peer Rating of Sensitivity: Following is a list of people you know and/or work with who are also participating in this study and a scale of sensitivity from 1. to 7. Please rate each individual, in comparison with other people you know, by placing next to their name the number corresponding to their level of interpersonal sensitivity as you see it. Peer Rating of Intelligence: Following is a list of people you know and/or work with who are also participating in this study and a.scale of intelligence from 1 to 7 . Please rate each individual, in comparison 
with other people you know, by placing next to their name the number corresponding to their level of intelligence as you see it. Self Rating of Sensitivity: On the scale below choose the number whlch represents what you believe to be the best description of your own interpersonal sensitivity in comparison with other people you know and clrcle that number. Self Rating of Intelligence: On the scale below choose the number which represents what you believe to be the best description of your own intelligence in comparison with other people you know and circle that number.

These measures were presented to subjects in six alternate forms. The Quick Test was administered first in every case. The ordering of the other five measures was random within the restriction that questions on sensitivity were alternated with those on intelligence. 


\section{Chapter 3}

\section{RESULTS}

The correlation matrix shown in Table 1 was generated by the manipulation of the two traits and three methods as discussed. Data from two subjects was dropped because of missing entries, leaving an N of 51. Examination of the matrix reveals that the primary hypothesis of this study was not borne out: there is no evidence of convergent validity on the Test of Sensitivity. Subhypothesis a) was found to be correct. Males and females scored comparably on the Test of Sensitivity. Statistical analysis showed no significant differences. (Eleven of thirteen descriptions in the Test require predictions about males.) Subhypothesis b) was not conflrmed. One-way analysis of variance showed no signiffcant differences among the ten groups on Test of Sensitivity scores. Significant differences $(F=4: 248$, df $=9, p=.05)$ were, however, found between groups on Intelligence. Group mean IQ scores ranged from 100.80 to 126.00 . Subhypothesis c) could not be tested because of the experimenter's fallure to locate suitable groups who were willing to particlpate in the study. (The only ongoing encounter group of which the experimenter was aware, at the Center for Student Development, did not have enough people who were willing to volunteer for this study.)

Twelve percent of the subjects in this study chose Smith's definition of sensitivity as their own. Eighty percent selected definitions which suggested that sensitivity means the ability to 
perceive and appreciate small differences or relate with care and concern to other people. (It should be noted that these alternative definitions of sensitivity were chosen arbitrarily.) 
Table 1

Multitrait Multimethod Matrix

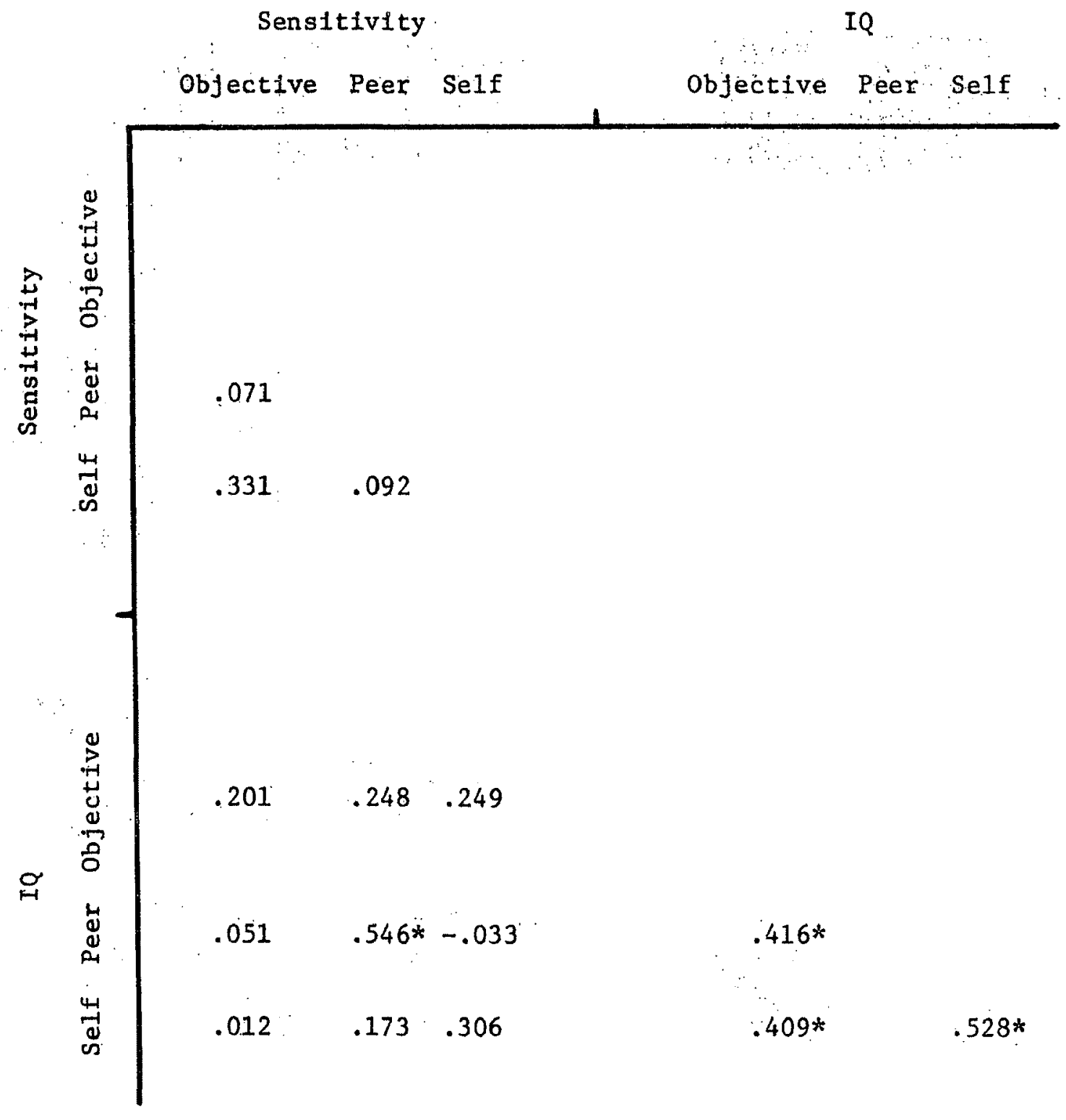

*Significant at .01 level

degrees of freedom $=49$ 


\section{Chapter 4}

\section{DISCUSSION}

Campbell and Fiske state that the basic requirement of convergent validity is that monotraitmheteromethod values be significantly different from zero and sufficiently large to encourage further examination of validity. It can be seen from the matrix that the appropriate monotrait-heteromethod entries for sensitivity are :071, .331, and .092. None of these values is significantly different from zero at the .01 probability level. However, corresponding values on the IQ measure are $.416, .409$, and .528 , a11 of wich are significant at the same probability level. The relatively high correlations in the monotrait-heteromethod entries for intelligence and low correlations in the comparable entries for sensitivity indicate that trait rather than method variance is responstble. It should be noted that with the exception of peer ratings, heterotralt monomethod correlations are nonsignificant (.201 objective, .306 self-rating). The Campbell and Fiske approach requires that 1dentical methods, in this case objectively scored tests; peer ratings and self ratings, be used to measure all traits of interest. It is this requirement that enables the distinction of trait and method variance to be made. If monotrait-heteromethod correlations are to be explained by variablity of the methods utilized, this must be true for both traits examined, and in the present study only one trait yielded insignificant correlations. Method variance should mask both sets of correlations, that is, the monotralt-heteromethod values for both sensitivity and intelligence. Thus, while method variance may have contributed 
to the Intelligence correlations, the same is true for sensitivity correlations, none of which reached significance at the .01 level. It is possible to conclude, then, that the multitrait multimethod approach does not provide convincing evidence for convergent validity on the Test of Sensitivity. The Ammons Quick Test, however, did show convergent validity with the other methods utilized.

Failure to discover convergent validity leaves us in the position of attempting to determine why there is a discrepancy between Smith's assertions that the Test should measure the general ablifty, sensitivity, and our present data. Cronbach and Meehl (1955) suggest that the Investigator in this position can interpret his results in three ways. 1) The test stmply does not measure the construct. 2) The theoretical network which generated the construct is unsound. 3) The experimental design failed to test the hypothesis correctly. Campbell and Fiske state clearly that their approach "is primarily concerned with the adequacy of a construct as determined by the confirmation of theoretically predicted assoctations with measures of other constructs. We believe that before one can test the relationships between a specific trait and other traits, one must have some confidence in one's measure of that trait. Such confidence can be supported by evidence of convergent and discriminant validation (p. 100)." In addition, however, Campbel1 and Fiske urge caution in the case of fallure to find convergent validation, which is, of course, the state of affairs in the present study. When 
the multitrait multimethod matrix shows no convergent validation there remain several alternative interpretations. Campbe11 and Fiske elaborate on Cronbach and Meeh1's statement of these alternative interpretations as follows: a) None of the measures used is adequate for measuring the trait. b) One or more of the measures does not measure the trait. c) The trait is not a functional unity (p. 104)." In this case establishment of discriminant validity would, of course, lend support to a given trait or construct as a distinct entity, and come close to what Cronbach and Meehl call construct validity. But when there is a fallure to find convergent validity, as in the present study, it is meaningless to go on to discuss discriminant validity. How then can we interpret the present data? Subject's responses to the question of their definftion of sensitivity indicate that the three methods utilized - the Test of Sensitivity, peer ratings and self ratings - were not measuring the same thing. Whatever the Test of Sensitivity measures, it seems clear that it does not tap the abilities or characteristics which subjects in this study associated with sensitivity. The fact that only twelve percent of these subjects share Smith's definftion of sengitivity corroborates this assertion that the Test of Sensitivity is not measuring sensitivity as it iq generally understood. Data from the present study is not conclusive with regard to the adequacy of Smith's sensitivity construct. One possibility is that the Test of Sensitivity does not measure sensitivity as a general ability 
but may measure one of the components suggested by $\mathrm{Cline}$ and Richards. Subfects in this study reported that the test required one to draw heavily on stereotypes in making predictions about each person described. Face validity of the Instrument certainly corroborates this possible Interpretation.

Unfortunately, these findings do not allow an adequate distinction between sensitivity and empathy. If we accept the Campbell and Fiske approach to the question of validity, a measure which shows convergence with highly dissimilar methods purported to measure the same trait must be devised. Only with good evidence of both convergent and discriminant validity could the discussion as to the relationship between sensitfvity and empathy proceed. Were such a measure of sensitivity available, an appropriate research strategy would be a multitrait multimethod approach using various methods of measuring sensitivity and empathy.

One further alternative needs clarification - the question of the adequacy of the present experimental design. One possible criticism is the fact that the Test of Sensitivity is self-administered, while the Ammons Quick Test requires an examiner. The high correlations between the Quick Test and other measures of intelligence should, however, alleviate this concern. Other requirements of the Campbell and Fiske approach have been met, as nearly as possible.

Campbell and Fiske's approach puts reliability and validity 
on a continuum, where "reliability is the agreement between two efforts to measure the same trait through maximally similar methods (and) valid1ty is represented in the agreement between two attempts to measure the same trait through maximally different methods (p. 83)." The Test of Sensitivity appears to be a case in point where high reliability does not necessar1ly insure validity. Although Smith has made an interesting attempt at empirical measurement in an area which deserves further attention, the Test of Sensitivity does not hold up when the criterion of convergence of independent methods is applied. 


\section{Chapter 5}

\section{SUMMARY}

This study attempted to Investigate the convergent and discriminant validity of Smith's Test of Sensitivity. The multitrait multimethod matrix of Campbell and Fiske was employed. Data were collected on a total of 53 subjects from 10 separate groups on two objectively scored tests, two peer ratings and two self ratings. Intelligence was chosen as the second trait examined for the purpose of establishing discriminant validity.

Results showed significant correlations between methods estimating intelligence, The correlations on measures of sensitivity across the same methods were not significant. (Both sets of correlations were examined at the .01 probability level.) The fallure to establish convergent validity across sensitivity measures was attributed to tralt rather than method variance. It is not possible to conclude from this data whether sensitivity per se is not a meaningful, unified construct, or, alternatively, whether Smith's construct sensitivity and the test designed to measure it simply fail to tap what is commonly associated with sensitivity. 


\section{REFERENCES}

Ammons, R. B., \& Ammons, C. H. The Quick Test (QT): Provisional Manual. Psychological Reports, 1962, 11, 111-161.

Bergin, A. E. \& Solomon, S. Personality and Performance Correlates of Empathic Understanding in Psychotherapy. In New Directions In Client-Centered Therapy. Eds. J. T. Hart and T. M. Tomlinson. Boston: Houghton Miffin, 1970. 223-236.

Campbel1, R. J., Kagan, N., and Krathwoh1, D. R. The Development and Valldity of a Scale to Measure Affective Sensitivity (Empathy). J, of Counseling Psychology, 1971, 18, 407-412.

Campbel1, D. T. \& Fiske, D. W. Convergent and Discriminant Validation by the Multitrait-Multimethod Matrix. Psychological Bulletin, $1959,56,81-105$.

Cline, V. B., \& Richards, J. M. Jr. Accuracy of Interpersonal Perception - A General Tra1t. J. of Abnormal Psychology, $1960,60,1-7$.

Cronbach, L. J. \& Meehl, P. E. Construct Validity In Psychologica1 Tests. In Problems in Human Assessment. Eds. D. N. Jackson and S. Messick. New York: McGraw Hi11, 1967. 57-77.

Smith, H. C. Sensitivity Training. New York: McGraw Hil1, 1973.

Truax, C. B. Effective Ingredients in Psychotherapy: An Approach to Unraveling the Patient-Therapist Interaction. J. of Counseling Psychology, 1963, 10, 256-263. 


\section{APPENDIX A}

\section{The Test of Sensitivity}

DIRECTIONS: How well can you predict the feellngs and behavior of people? In each of the following actual cases some information is given about a person. Study the facts, then pick the answer to each statement that you think is correct. Circle. ' $\mathrm{T}$ ' on the answer sheet if you think the statement is true; ' $F$ ' if you think it is false. The correct answers are known from more complete information about the individuals.

Amos

Amos is the traffic manager for a Milwaukee brewery. He was promoted from the driver ranks and possesses a fourth-grade educational background. He is very loyal to the company and has high moral standards. When working in the ranks, he gained the reputation of being the hardest-working driver. He is a big man and says, "Hard work never hurt anyone."

$T^{*} \mathrm{~F}$ 1. He works ten to twelve hours a day and six to seven days a week:"

$T^{*} F$ 2. He believes his employees should be paid on a commission basis.

T F* 3. He feels that the union's seniority rule is as good a basis as any for promoting helpers to drivers.

T* F 4. He tries to promote his product at all times, even to the point of losing friends.

Betty

Betty is the tall and slender receptionist of a university dean. Thirtynine years old, she has top senforlty among the seven girls in the office. The job requires that she meet the large number of students who have been asked to see the dean or who come to him for advice. She refers to students as "dumpbells," openly blames them for their errors, and swears, when she is angry, which she often is.

T F* 5. She consults the other girls about the regulation of the heat and vent1lation in the office.

I F* 6. She compliments the other girls when they do a good job. T* F 7. She was an only child.

T F* 8. She is dependable about passing along phone messages she receives for the other girls.

Christopher:

Christopher's parents live in a small western town where his father 
teaches school and his mother is a 1ibrarian. Both parents are shy and quiet, fond of reading and natural history. His brother, five years older, is now a lawyer. Christopher has always been thin and frail but seldom.111. He began to talk early, but did not walk early. He seldom crled and required ilttle discipline as a child. His intelifigence test scores are considerably above those of the average college student.

T. F* 9. Christopher seldom daydreamed.

T F* 10. He enfoyed his school gang.

$T^{*} F$. 11. He feels that he is not a true participant in iffe.

$\mathrm{T}: \mathrm{F}^{*}: 12$. While in college he went to many movies.

$\mathrm{T*} F$ 13. He creates imaginary friends.

T F* 14. He enjoyed high school activities.

T* F 15 Occasionally, when excited, he loses his voice.

T F* 16. His college grades are lower than the grades of other students of his intelifgence.

Dorian

When he first came to Harvard Dorian was a tall, narrow-shouldered, twenty-four year-old graduate student in engineering. He was born on a farm in Wisconsin, the youngest of: a large family. He received most of his education at country schools unt1l he entered engineering college: Recalling his family and childhood Dorian sald, "My earliest impressions of life that I can remember now were to a large extent miserable. As a baby I was constantly alling, apparently having one childhood disease after another, starting off with measles at the age of six weeks. Mother was an intelligent, gentle, loving woman, and was much thought of by friends and neighbors. My father was at times a brutal man and inclined, when drinking, to be unpleasant to me. At such times he would make fun of me, call me all sorts of unpleasant names and say that I probably wouldn't live out the year, and that it would be better if I didn't. My father had become an invalid, I

forgot to mention before, shortly after mother died. He was in acute need of a job, for he had no money, and was living on what he could. borrow from a brother. He was earning his meals by working in a restaurant."

Dorian was one of fifty college students hired for an intensive study of personality at Harvard in the 1930s.

$T^{*} \mathrm{~F}$ 17. In an experiment Involving a mild electric shock, Dorian was unusually disturbed.

$T^{*} F$ 18. He had some difficulty in recalling the names and ages of his brother and sisters.

T F* 19. Dorian was a good conversationalist.

T* F 20. He had recently become a Christian Scientist.

Edgar

Edgar is sixteen years old. A bit slight for his age, he is a mediumbrown Negro boy, the oldest of four children in a middle-class New 
Orleans famlly. His mother is a physically powerful woman, religious, dominant, and thrifty. She has been the head of the family since the father deserted seven years ago. She insists on well-mannered and obedient children. Edwar's father was a semiskilled worker. Before he deserted the fam1ly the mother had declded that Edgar would be a doctor. Now she works to keep up appearances and to keep the children in school. Edwar was not to bring "lower-class" children home or to play. with them. He had to stay in the yard after 4 P.M. His mother frequently used beating in disciplining her children. In spite of money problems his mother arranged for Edgar to attend a private Negro prep school. He was above average intelligence and maintained good academic and athletic records throughout school.

$T^{*} \mathrm{~F}$ 21. He is severely punished by his mother when he exhibits curiosity about sex.

T F* 22. He shows few signs of anxiety or worry.

$T^{*} F$ 23. He saves his money to buy good clothes.

T F* 24. He feels strongly that lower-class Negroes are unfairly persecuted.

$T^{*}$. F 25. He says, "I'm as good as anybody in the world."

$T * F$ 26. He is verbally but not physically aggressive.

$T F^{*}$ 27. He is proud of his mother.

T* F. 28. He is boastful.

Frank

Frank entered Dartmouth College from a private school and graduated as an economics major. He was of slight build, average height, good health, a very superfor intelligence. An observer who had known him and his family for a long time commented, "The only child of very admiring and doting parents, during his precollege life he was brought up to be a perfect gentleman; so much so, in fact, that he failed to reveal the usual boyish traits as completely as he should have. As he grew older, he veered from the exemplary behavior and developed a reputation of being a great ladies' man, driving somewhat recklessly, and being indifferent to the serious aspects of living. At times, his appearance is very smooth, and then again he is quite neglectful and looks extremely seedy. The mother has been a semi-invalid during all of the boy's life and has dominated him, and I believe imposed upon him beyond reason."

T* F 29. When asked what superpoliteness expressed, he replied, "contempt:"

$T^{*} \mathrm{~F}$ 30. Fellow students think of him as a "snob."

T $F^{*}$ 31. Frank recelved high grades in college.

T F* 32. Frank has few artistic interests. 


\section{George}

George was the second son of Irist Immigrant parents who had grade school educations. His father's earnings were meager at first but Improved when encouraged by his wife. He 1nvested a small inheritance In a flower shop. George's mother felt that education was less important than rellglon, but necessary for gettlng ahead soclally. She was very affectionate, but dominating. George's parents dectided he should be a doctor. His father was rather passive, but capable of outbursts. Punishment of the children was severe. It included shaming, denying of affection, spanking, and denying of pleasure. As a child George was his parents' favorite, and was often the center of attraction. He was good-looking, and was considerably above average intelligence. Later, however, he lost favor when his brothers made more social progress.

T $F^{*}$ 33. He found it easy to make decisions.

$T^{*} \mathrm{~F}$. 34. He had very strong guilt feelings about masturbation.

T* F 35. He acted childish in high school.

$T^{*} \mathrm{~F}$ 36. He was a "show-off" in kindergarten

$T * F$ 37. He bragged about his sexual conquests.

$T^{*}$. F 38. He bragged about being so young in high school.

$T$ F* 39. He was very studious.

T. F* 40. He found it much easier to get along with boys than girls.

Mrs. Harrison

Margaret Harrison is the owner and manager of an independent woman's ready-to-wear shop in a suburb of Cleveland. She also does. all the buying, which means leaving the shop in charge of a saleswoman twice a year while she is $1 \mathrm{n}$ New York. She is married to a man who is lame. Because of this he has refused to work for quite some time. He does odd jobs around the store and gives orders to the employees. He drinks heavily. Mrs. Harrison is about fifty-five years old. She is large, sturdy, and extremely intelligent. She has had a great deal of experience in the retail field. She is in the upper middle class. She is industrious and ambitious, but has a quick temper and never admits a mistake.

There are five saleswomen, two maids, and ten alteration women working for her. They receive excellent pay and work from 9:00 A.M. to 5:30 P:M. with an hour off for lunch. The merchandise in the shop is extremely high-priced, and consequently the customers are very wealthy, high-society people.

T F* 41. Mrs. Harrison is liked by her employees.

$T^{*} \mathrm{~F}$. 42. She is constantly enlarging her shop.

$T \quad F^{*}$ 43. She let her employees take a tenminute break in the afternoon.

$T^{*}, F$ 44. She doesn't hesitate to state her opinion if she disagrees with a customer's taste in clothes. 
John

John at fifteen was five feet four and weighed 105 pounds. He had a childhood record of 111 health. John was usually reserved but sometimes expressed himself forcefully. He was not at home in social gatherings, though he often attended. He enjoyed talking about books, art, politics, and movle stars. He got good marks in 1iterature and language, but poor ones in math. John grew up in a middle-class suburban area. His father provides a modest income as a plumber. He is patient and frlendly with John. John's mother, the dominant figure in the household, is often apprehensive about his safety and demands much of his time.

T* F 45. John is unusually fearful of his emotional impulses.

T* F 46. John stated, "I wish my mother could be happier."

$T$ F* 47. John saw himself as seldom worrying about things which he had done, but never told to anyone.

T F* 48. John felt that radical agitators should not be allowed to make speeches.

$\operatorname{Kar1}$

Kar1, a Dartmouth student, was a cheery, sociable, and conventional young man of average intelligence who was earnest and diligent in his college work. He graduated, however, in the lowest tenth of his class. He had consdierable feelings of inferiority and has a fear of making independent judgments. His completions of incomplete sentences ("artiflcial as the ice cream in a soda fountaln window," "exclting as a battle between a mongoose and a cobra," "Idealistic as the life of a nun," etc.) indicated that $\operatorname{Karl}$ had a creative capacity that had not been used in his academic work. Both of his parents were talented musicians but he could not carry a tune or play an instrument.

T* $F$ 49. In his autobiography he wrote that he was "the most eventempered cuss that has ever walked on two feet."

$T^{*} F$ 50. About the same number of friends described him as "eventempered" as described him as "quick-tempered".

$T^{*} \mathrm{~F}$ 51. Kar1 was unable to organize and present ideas clearly.

T F* 52. He clearly distinguished between what he thought from what others expected him to think.

\section{The Lawrences}

William Lawrence, twenty-four, and Laura, twenty-three, have been married for a year and a half. Both his and her parents had approved of their marriage. Their parents were foreign-born, were similar in social and economic backgrounds, and lived in the same community. At the time of their marriage, William had had only irregular employment since his graduation from high school. William is proud of his dead mother. She had run her husband's affairs, planned her seven children's vocational and soclal activities, and faced death with an unsagging 


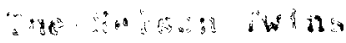

spirit. The youngest of his three sisters, all of whom were much $11 \mathrm{ke}$ theirmother, took:care of him when their mother died. Laura, although she lwanted Tto teach iktndergarten, had worked as a store clerk for two ayears before her marrlage and continued to work at the same fob afterward $\mathrm{s}_{\mathrm{n}}$. Her father had been a successful merchant. However, he developed an Interest in gambling and had given up several good posittons impulsively. He often gave Laura and her mother tongue Iashings.: Her mother.was rpatient and long suffering. The Lawrences had few friends and belonged to no social organizations.

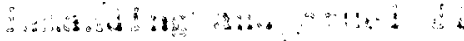

T*.. F 53: W1111am expecred his wife to do many things for him.

T* F, 54. His mother was also named Laura.

T*: F : 55. $\mathrm{He}$ feels that his childhood was happy.

$\mathrm{T}$. $\mathrm{F}^{\star}$ 56. He knows that he wants to depend on his wife as he used to depend upon his mother and sisters.

T*..F. $57 .:$ Wiliam commenting on getting married, said, "With

$\therefore \quad \therefore \quad$ superhuman effort I forced myself to go to the courthouse $\because \cdots:$ and say " $I$, want a 1 icense."

T F* 58. Laura continued to respect her father even after he had an $:$ ceased to support the family.

T* F 59. William considers his marriage a mistake.

T: F* 60. W1111am st111 greatly admires his wife's appearance and personality.

The Medford Twins

$$
\text { 11. } 15 . . . \quad \therefore \quad . .
$$

Ear1, and Frank, identical twins, were born in a Midwestern city, of uneducated and unmarried parents. When the boys were six months old, they were, turned over to their mother's sister. She kept Frank but placed Earl with a famlly who had advertised their wish to board a baby. This family soon assumed full responsibility for Earl and took him to a city in the Northwest without consulting the aunt of the two boys. Earl's foster father was a college graduate and a successful salesman; Frank's a streetcar conductor. Earl graduated from college; Frank attended high school only six months, though later he attended night school. Earl was ralsed in comfort; Frank was brought up by hts fond aunt with 11ttle economic security in the neighborhood where he was born. Both twins had happy homes with only moderate discipline.

Mark " 1 " for Ear 1 and " 2 " for Frank

$12 * 61$. Was less pompous and affected.

$12 * 62$. Sald that what he wished for most was the happiness of his family.

1* 2 63. Was more eager to impress people.

1* 2 64. Sald that what he wanted most in life was a good business with men working for him.

$12 * 65$. Was more emotional

$1 * 2$ 66. Was more timid and self-conscious.

1* 2 67. Was more disturbed by his failure to achieve his ambitions.

$12 * 68$. Was more friendly in his personal relations. 
Fred and John, 1dentical twins, had very similar backgrounds and personallty !s Thelry fatherg an unsuccessful and alcohollc son of a well-todo father, had gone to Cuba to make his fortune. He failed there as a farmeroand also failed in Florida where the family had moved when the boys were four years old. He eventually returned to New England to diveowith the twins grandmother. The mother of the twins was Industrious and long-sufferlng. Though she was, for the most part, responsible for rearling the children, their father was sporadically a demanding and cruel. disctplinartan. The twins left school after the elghth grade and went to work in the same factory on semiskilled jobs. They are working at identical jobs today. They have the same eye and hair color,.. and look: very much alike. Both have type $O$ and RH positive blood. Both are shy, dependent, passive, and anxious.

The twins came to the attention of physicians at the age of forty-six because John had developed a severe duodenal ulcer while Fred remained in good health. For each of the statements below indicate the name of the twin to whom you think the statement applies.

Mark "1": for Fred and "2" for John

1* 2 69. Had better understanding of himself and of other people.

$1 * 2$ 70. Was more optimistic.

1. 2* 71. Showed greater hatred of his father.

1* 2 72. Described his wife as a good cook and mother.

1. $2 * 73$. While the level of gastric secretion was much higher than normal in both twins, his level was higher than his brother's.

1. 2* 74. Was more resentful that their mother had not given them more from the $\$ 100,000$ she inherited about ten years ago.

$1 * 2$ : 75. Was a warmer and more tender person.

$1^{*}: 2$ 76. Was readier to accept blame. 


\section{APPENDIX B}

This pilot study attempted to determine the wording of the question which would produce the broadest range on the seven point scale. The. two cholces examined were:

"On the basis of the seven point scale above, rate the person - . on intelligence, in comparison with the other people you know."

"On the basis of the seven point scale above, rate the person - . on Intelligence, in comparison with the general population."

The scale was identical to that utilized in peer and self ratings. Results Indicated a broader range on the scale was chosen when the Instructions read "in comparison with the other people you know." 